\title{
MLH1 Gene Promoter Hypermethylation
}

National Cancer Institute

\section{Source}

National Cancer Institute. MLH1 Gene Promoter Hypermethylation. NCI Thesaurus.

Code C158920.

A genetic finding indicating that an excess of DNA methylation in the promoter region of the MLH1 gene has been detected in a sample. 